\title{
GSN wt Allele
}

National Cancer Institute

\section{Source}

National Cancer Institute. GSN wt Allele. NCI Thesaurus. Code C150252.

Human GSN wild-type allele is located in the vicinity of $9 q 33.2$ and is approximately 125 $\mathrm{kb}$ in length. This allele, which encodes gelsolin protein, plays a role in both assembly and disassembly of actin filaments. Mutation of the gene is associated with Finnish type familial amyloidosis (amyloidosis V). 